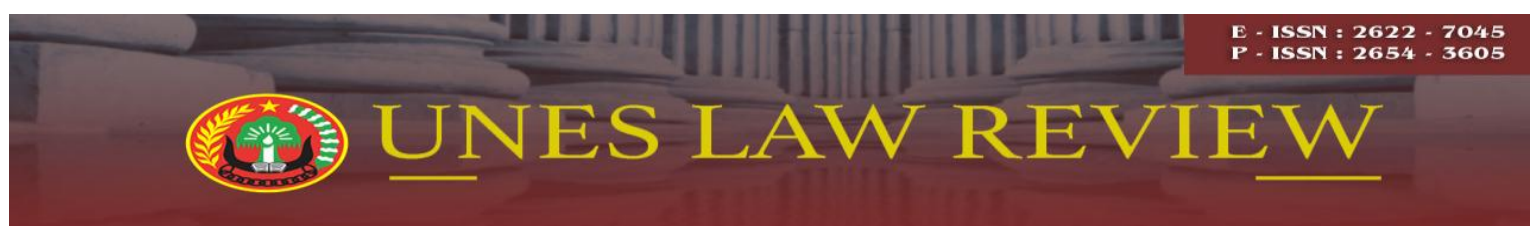

Email: uneslawreview@gmail.com

Online: http://review-unes.com/index.php/law

Volume 2, Issue 3, Maret 2020

\title{
LEMBAGA DEPONERING SEBAGAI IMPLEMENTASI ASAS OPORTUNITAS PERKARA PIDANA DI INDONESIA
}

\author{
Gema Yudha \\ Advokat Law Firm Descova, Padang Panjang, Indonesia \\ Email: gemayudha20@gmal.com
}

\begin{abstract}
Deponering or exclusion of a criminal case for the sake of interest is the authority of the Attorney General of the Republic of Indonesia in accordance with the provisions contained in Article 35 sub c of Law No. 16 of 2004 concerning the Basic Provisions of the Attorney General's Office of the Republic of Indonesia, as well as their explanations. Leaving aside the case as referred to in this provision is the implementation of the principle of opportunity in which a case (criminal act) when it is submitted to a trial is expected to cause a shock in the community or by trial the case will have a negative effect on the wider community, as happened in the case of Bibit Samad Rianto and Chandra M. Hamzah that occurred in 2009 until 2011. The problem studied was about the position of deponering institutions as the implementation of the principle of opportunity by the Attorney General and what were the reasons for the Attorney General to decide on deponering of Bibit Samad Rianto and Chandra M. Hamzah cases? This research is supported by primary data secondary data in the form of interviews with the parties in the Center for Research and Development of the Attorney General's Law. From the results of research and analysis obtained that the existence of deponering institutions as the implementation of the principle of opportunity by the Attorney General is a prosecution must be done if formal requirements have been met and must also be deemed necessary in the public interest, so that the prosecutor will not demand a case before the elements of public interest has been fulfilled. And the reason the Attorney General decided to deponering the Bibit Samad Rianto and Chandra M. Hamzah case was based on the consideration that if the case in the name of the suspects Bibit Samad Rianto and Chandra M. Hamzah was transferred to the court, it would have the effect of disturbing the performance of the Corruption Eradication Commission (KPK). as well as managerial in carrying out their duties and authorities, so as to prejudice the public interest, namely the interests of the nation, state or society and also in order to protect efforts to eradicate corruption as a whole.
\end{abstract}

Kata Kunci: Deponering, Asas Opportunitas, Hukum Acara Pidana

\section{PENDAHULUAN}

Kejaksaan merupakan suatu institusi dalam sistem peradilan pidana yang memiliki fungsi menuntut dan membuat dokumen seperti surat dakwaan dan surat tuntutan. Jaksa adalah tokoh utama dalam penyelenggaraan peradilan pidana. Kejaksaan Republik 
Indonesia adalah suatu badan yang fungsinya berkaitan dengan kekuasaan kehakiman menurut Undang -Undang Dasar 1945 (UUD 1945) dan merupakan lembaga pemerintahan yang melaksanakan kekuasaan negara di bidang penuntutan serta kewenangan lain berdasarkan undang-undang. dilakukan secara merdeka yang diselenggarakan oleh Kejaksaan Agung, Kejaksaan Tinggi dan Kejaksaan Negeri.

Kejaksaan dalam penuntutan perkara menganut asas legalitas \& asas oportinitas. Kedua asas tersebut berada pada posisi yang berlawanan, di satu pihak asa legalitas menghendaki dilakukannya penuntutan terhadap semua perkara pengadilan tanpa terkecuali. Sedangkan di sisi lain asas oportunitas memberikan peluang bagi penuntut umum untuk tidak melakukan penuntutan perkara pidana di pengadilan. Oleh karena itu asas oportunitas diartikan sebagai asas yang memberikan wewenang kepada penuntut umum untuk menuntut atau tidak menuntut dengan atau tanpa syarat seseorang atau korporasi yang telah mewujudkan delik demi kepentingan umum (the public Prosecutor may decide to prosecute or not to prosecute, whether conditionally or not). Asas tersebut memberikan wewenang kepada Penuntut Umum untuk meniadakan penuntutan hukum terhadap seseorang yang disangka telah mewujudkan suatu perbuatan pidana berdasarkan pertimbangan, bahwa lebih menguntungkan kepentingan umum jikalau tidak diadakan penuntutan.

Perkara yang dikesampingkan demi kepentingan umum oleh Jaksa Agung diantaranya adalah perkara atas nama tersangka Chandra M. Hamzah dengan Surat Ketetapan Mengesampingkan Perkara Demi Kepentingan Umum Nomor: TAP-001/A/JA/01/2011 tertanggal 24 Januari 2011, dan perkara atas nama tersangka Dr. Bibit Samad Rianto dengan Surat Ketetapan Mengesampingkan Perkara Demi Kepentingan Umum Nomor: TAP-002/A/JA/01/2011 pada tanggal 24 Januari 2011, yang mana keduanya disangka telah melakukan tindak pidana korupsi. Hal ini didasarkan pada pertimbangan bahwa apabila perkara atas nama tersangka Chandra M. Hamzah dan tersangka Dr. Bibit Samad Rianto dilimpahkan ke Pengadilan akan dapat berakibat terganggunya kinerja Komisi Pemberantasan Korupsi (KPK) dalam melakukan tugas dan kewenangannya sehingga merugikan kepentingan umum yaitu kepentingan bangsa, negara dan atau masyarakat. Yang menjadi permasalahan dalam penelitian ini adalah : 
1. Kedudukan lembaga deponering sebagai implementasi asas opportunitas oleh Jaksa Agung?

2. Apakah alasan Jaksa Agung memutuskan deponering terhadap kasus Bibit Samad Rianto dan Chandra M. Hamzah?

\section{METODE PENELITIAN}

Pendekatan yang digunakan dalam melakukan penelitian tentang peran deponering sebagai implementasi asas opportunitas dalam perkara pidana di Indonesia, adalah pendekatan yuridis normative, di dukung pendekatan yuridis empiris. Pendekatan yuridis normatif digunakan untuk melihat aturan-aturan hukum yang terkait dengan deponering pada kasus tindak pidana korupsi di Indonesia. Sedangkan pendekatan yuridis empiris digunakan untuk melihat bekerjanya aturan hukum tersebut di masyarakat.

Data yang digunakan dalam penelitian ini yaitu data sekunder sebagai data utama dan data primer sebagai data pendukung. Untuk memperoleh data sekunder terkait pelaksanaan peran deponering sebagai implementasi asas oportunitas dalam perkara pidana di Indonesia, maka digunakan teknik pengumpulan data melalui penelitian kepustakaan (library research) atau studi dokumen. Dengan mengadakan penelitian kepustakaan diperoleh data awal untuk digunakan dalam penelitian lapangan (field research). Studi kasus bersumber dari media sosial tentang kasus Chandra dan Bibit, serta Bambang Wijayanto dari KPK - RI. Untuk memperoleh data primer digunakan teknik pengumpulan data melalui studi lapangan dengan teknik wawancara. Adapun pihak-pihak yang diwawancarai dalam penelitian ini adalah: 1) Staf Pusat Penelitian dan Pengembangan Hukum Kejaksaan Agung; 2) Staf Penerangan Hukum; 3) Staf Jaksa Agung Muda Bidang Tindak Pidana Khusus.

\section{HASIL PENELITIAN DAN PEMBAHASAN}

\section{Lembaga Deponering Sebagai Implementasi Asas Oportunitas Oleh Jaksa Agung Republik Indonesia}

Asas oportunitas ditafsirkan secara negatif, yaitu penerapannya haruslah selalu merupakan suatu keistimewaan (uitzondering) terhadap kewajiban umum untuk melakukan penuntutan terhadap setiap tindak pidana. Tujuan asas oportunitas ini tidak lain hanyalah untuk memperlunak ketajaman (scherpte) yang terdapat pada asas legalitas. Penafsiran 
secara positif berarti bahwa suatu penuntutan haruslah dapat dilakukan jika telah terpenuhi syarat-syarat formil dan haruslah pula dianggap perlu untuk kepentingan umum, sehingga jaksa tidak akan menuntut suatu perkara sebelum unsur kepentingan umum tersebut telah terpenuhi, yaitu apakah suatu penuntutan itu benar-benar dikehendaki oleh kepentingan umum atau tidak.

Pengaturan mengenai asas oportunitas sesuai dengan perundang-undangan terkait Undang-Undang Kejaksaan Republik Indonesia yang mengatur sebagai salah satu proses deponering antara lain:

1. Pasal 8 Undang-Undang Nomor 15 Tahun 1961 tentang ketentuan-ketentuan pokok Kejaksaan Republik Indonesia

2. Pasal 32 huruf c Undang-Undang Nomor 5 Tahun 1991 tentang Kejaksaan Republik Indonesia

3. Pasal 35 huruf c Undang-Undang Nomor 16 Tahun 2004 tentang Kejaksaan Republik Indonesia

Bahwa seharusnya memang demi kepentingan umum ini memiliki parameter tersendiri, tidak cukup hanya pada frasa kepentingan umum adalah kepentingan bangsa, negara ataupun masyarakat luas. Masing-masing dari frasa bangsa, negara, dan masyarakat luas haruslah diberi parameter. Apabila tidak memiliki parameter yang jelas, maka kepentingan umum ini dinilai terlalu lentur sehingga memiliki implikasi yaitu pemegang kuasa dapat menafsirkannya secara bebas. Di Indonesia wewenang mengesampingkan perkara demi kepentingan umum (deponering) didasarkan atas 3 (tiga) alasan yaitu:

1. Perkara dikesampingkan karena alasan kebijakan (policy) antara lain; tindak pidananya ringan, pelakunya sudah tua, kerusakan telah diperbaiki dan kerugian sudah diganti.

2. Perkara dikesampingkan karena alasan teknis (tidak cukup bukti, lewat waktu, dan sebagainya).

3. Melalui penggabungan, yaitu menggabungkan perkara tersangka dengan perkara lain yang sudah diajukan ke pengadilan.

Didalam penjelasan Pasal 35 huruf c Undang-Undang Nomor 16 Tahun 2004 hanya menyatakan "kepentingan umum" adalah kepentingan bangsa dan negara dan/atau kepentingan masyarakat luas. Kemudian dengan adanya kata-kata "setelah memperhatikan saran dan pendapat dari badan-badan kekuasaan negara yang mempunyai hubungan dengan masalah tersebut" menjadi makin kabur pengertiannya. Menjadi kabur karena siapakah badan-badan kekuasaan negara yang mempunyai hubungan dengan masalah 
tersebut? Hal ini berarti wewenang oportunitas ini dibatasi sehingga tidak ada kepastian hukum dalam penerapannya.

\section{Kriteria Kepentingan Bangsa dan Negara dan/atau Masyarakat Luas Sebagai Penjelasan "Kepentingan Umum" Dalam Penyampingan Perkara Demi Kepentingan Umum}

Kepentingan umum dalam penerapan asas oportunitas adalah keputusan untuk tidak menuntut karena alasan kebijakan, yakni deponering. Kepentingan umum dalam hal ini adalah kepentingan bangsa dan negara dan/atau masyarakat luas, sehingga perlu dibuat suatu kriteria tentang kepentingan umum tersebut untuk dijadikan pedoman bagi Jaksa Agung dalam menerapkan wewenangnya melakukan deponering. Bahwa kepentingan umum yang dimaksud merujuk pada pendapat J.M Van Bemmelen, terdapat 3 (tiga) alasan untuk tidak dapat melakukan penuntutan yaitu:

a. Demi Kepentingan Negara (staatsbelang)

Kepentingan negara tidak menghendaki suatu penuntutan jika terdapat kemungkinan bahwa aspek-aspek tertentu dari suatu perkara akan memperoleh tekanan yang tidak seimbang. Sehingga kecurigaan yang dapat timbul pada rakyat, dalam keadaan tersebut menyebabkan kerugian besar pada negara. Contohnya ialah bila terjadi penuntutan akan berakibat suatu pengumuman (openbaring) yang tidak dikehendaki dari rahasia negara.

b. Demi Kepentingan Masyarakat (maatschapelijk belang)

Tidak dituntutnya perbuatan pidana karena secara sosial tidak dapat dipertanggung-jawabkan. Termasuk dalam kategori ini tidak menuntut atas dasar pemikiran-pemikiran yan telah atau sedang berubah dalam masyarakat. Contohnya pendapat-pendapat yang dapat berubah atau sedang berubah tentang pantas tidaknya dihukum beberapa delik susila.

c. Demi Kepentingan Pribadi (particular belang)

Termasuk didalamnya kategori-kategori bila kepentingan pribadi menghendaki tidak dilakukannya penuntutan ialah persoalan-persoalan hanya perkara-perkara kecil. Penyampingan perkara yang dilakukan demi kepentingan pribadi dapat merugikan, jika keuntungan yang diperoleh dari penuntutan adalah tidak seimbang dengan kerugian-kerugian yang timbul terhadap terdakwa dan masyarakat, maka kepentingan negara akan sangat dirugikan. 
Kepentingan umum dalam suatu negara mempunyai peranan aktif dan peranan pasif. Dalam peranan aktif, kepentingan umum menuntut eksistensi dari hukum dan sebagai dasar menentukan isi hukum agar tujuan hukum dapat dicapai. Kepentingan umum yang dimaksud dalam hal ini adalah mengenai cita-cita hukum. Sedangkan dalam peranan pasif, kepentingan umum yang diatur dalam suatu peraturan hhukum apabila dilanggar tidak dapat dijadikan sebagai landasan oportunitas untuk menyampingkan perkara pidana. Sebab kepentingan umum menuntut agar diadakan penuntutan di muka hakim pidana untuk dijatuhkan pidana yang setimpal.

Di bawah ini dapat dibandingkan antar kepentingan negara dan kepentingan masyarakat yang harus dilindungi dalam hubungannya dengan pelaksanaan asas oportunitas, yaitu:

1) Apabila tindak pidana itu menimbulkan kerugain bagi negara dan tidak terhadap kepentingan masyarakat, sedangkan kerugian dari akibat tersebut dirasakan tidak mempengaruhi jalannya pemerintahan, maka perkara itu dapat dikesampingkan.

2) Apabila tindak pidana tersebut tidak merugikan bagi kepentingan penyelenggara negara namun berakibat terganggunya kehidupan masyarakat atau timbulnya ketidakadilan dalam masyarakat, maka perkara tersebut tidak dapat dikesampingkan.

\section{Badan-Badan Kekuasaan Negara Dalam Penyampingan Perkara Demi Kepentingan Umum}

Penyebutan istilah "badan-badan kekuasaan negara" dalam penjelasan Pasal 35 huruf c Undang-Undang Nomor 16 Tahun 2004 tentang Kejaksaan Republik Indonesia tidak menjelaskan lebih lanjut siapa yang dimaksud dengan badan-badan kekuasaan negara tersebut, karena istilah "badan-badan kekuasaan negara" adalah lembagalembaga negara yang wewenangnya meliputi kekuasaan-kekuasaan negara, sebagaimana dalam sistem pemerintahan Republik Indonesia kekuasaan negara dijalankan oleh:

a. Lembaga negara yang memegang kekuasaan Legislatif, yaitu:

1) Majelis Permusyawaratan Rakyat (MPR);

2) Dewan Perwakilan Rakyat (DPR);

3) Dewan Perwakilan Daerah (DPD). 
b. Lembaga negara yang memegang kekuasaan Eksekutif, yaitu:

1) Presiden dan;

2) Wakil Presiden dibantu para menteri kabinet.

c. Lembaga negara yang memegang kekuasaan Yudikatif, yaitu:

1) Mahkamah Agung (MA);

2) Mahkamah Konstitusi (MK);

3) Komisi Yudisial (KY).

Dalam hal "badan-badan kekuasaan negara" yang dapat memberikan saran dan pendapat kepada Jaksa Agung, tentu adalah lembaga/institusi dari eksekutif, legislatif dan yudikatif yang telah disebutkan diatas, yang merupakan lembaga negara yang menurut pertimbangan Jaksa Agung "mempunyai hubungan dengan masalah tersebut" sesuai dengan penjelasan Pasal 35 huruf c Undang-Undang No. 16 Tahun 2004 tentang Kejaksaan Republik Indonesia sebagaimana tersebut diatas, atau yang memiliki tupoksi di bidang hukum maupun lembaga/institusi negara yang relevan/terkait dengan kasus/perkara yang hendak dideponir.

\section{Lembaga Deponering Sebagai Implementasi Asas Oportunitas Dalam Sistem Hukum di Indonesia}

Ditinjau dari Kitab Undang-Undang Hukum Pidana (KUHP) yaitu kitab yang mengatur mengenai perbuatan pidana secara material di Indonesia. KUHP yang sekarang masih berlaku adalah KUHP yang bersumber dari Hukum Kolonial Belanda, yakni Wetboek Van Strafrecht Voor Nederlands-Indie. KUHP adalah peraturan Perundang-Undangan yang menjadi dasar hukum pidana di Indonesia yang merupakan dasar hukum bagi aparat hukum seperti; Kepolisian, Kejaksaan, Pengadilan dan BadanBadan penegak hukum lainnya didalam menajaga dan menerapkan perkara-perkara pidana di Indonesia, kecuali ada Undang-Undang khusus yang telah disahkan atau dibuat bagi tindak pidana di Negara Indonesia, hingga berlaku asas "Lex Spesialis Derogat Lex Generalis" (hukum yang khusus menyampingkan hukum/peraturan yang umum).

KUHP berlaku di Republik Indonesia sejak 26 Februari 1946 dengan UndangUndang No. 1 Tahun 1946 baru hanya berlaku pada wilayah Jawa dan Madura. Pada 20 September 1958 dengan terbitnya UU No. 73 Tahun 1958 tentang berlakunya UU No. 1 Tahun 1946 (KUHP), bagi seluruh wilayah Indonesia, setelah itu lalu ada perubahan 
dann penyempurnaan disana-sini tentang isi KUHP tersebut. PPRI No. 27 Tahun 1983 tentang pelaksanaan Kitab Undang-Undang Hukum Pidana (KUHP) secara utuh / keseluruhan masih berlaku, kecuali beberapa pasal yang ditiadakan/dihapus atau dibuat khusus untuk itu.

Didalam Sistem Hukum Pidana di Indonesia, menyebutkan bahwa setiap peristiwa/tindak pidana yang dilakukan orang dan Badan Hukum di wilayah Republik Indonesia berlaku Hukum Pidana sesuai KUHP dan atau Perundang-Undangan khusus dibuat untuk itu, tanpa terkecuali.

Berdasarkan Undang-Undang No. 31 Tahun 1999 tentang Pemberantasan Tindak Pidana Korupsi yang disahkan pada 16 Agustus 1999, pada Pasal 9 BAB II berbunyi;

a. Setiap orang yang secara melawan hukum melakukan perbuatan memperkaya diri sendiri atau orang lain atau suatu korporasi yang dapat merugikan keuangan negara atau perekonomian negara, dipidanakan penjara dengan penjara seumur hidup atau pidana penjara paling singkat 4 (empat) tahun dan paling lama 20 tahun dan denda paling sedikit Rp 200.000.000 (dua ratus juta rupiah) dan paling banyak Rp 1.000.000.000 (satu milyar rupiah).

b. Dalam hal tindak pidana korupsi sebagaimana dimaksudkan dalam ayat (1) dilakukan dalam keadaan tertentu, pidana mati dapat dijatuhkan.

Hal tersebut mengandung arti bahwa tidak ada pengecualian setiap warga negara Indonesia yang melakukan tindak pidana korupsi: untuk dituntut dan diperlakukan hukuman pidana baginya, apabila sudah terbukti dan berkekuatan hukum.

Undang-Undang No. 7 Tahun 2006 tentang pemberantasan tindak pidana korupsi telah mengganti UU No. 31 Tahun 1999 dan UU No. 20 Tahun 2001 tentang pemberantasan tindak pidana korupsi. Dengan adanya UU tentang tindak pidana korupsi, maka pemerintah merasa perlu adanya suatu Badan Independen dibawah Presiden yang melaksanakannya. Untuk itu pada tahun 2002 berdasar pada UU No. 30 Tahun 2002, terbentuklah Komisi Pemberantas Korupsi (KPK) yang berkedudukan di ibu kota negara, Jakarta. Kemudian menyusul dibuat/pisahkannya Undang-Undang No. 10 Tahun 2015 tentang penetapan peraturan pemerintahan pengganti Undang-Undang No. 1 Tahun 2015 tentang perubahan atas UU No. 30 Tahun 2002 tentang Komisi Pemberantasan Tindak Pidana Korupsi menjadi Undang-Undang. Selanjutnya disahkan pula UU No. 19 Tahun 2019 tentang perubahan kedua atas UU No. 30 Tahun 2002 tentang Komisi Pemberantasan Tindak Pidana Korupsi. 
Pemerintahan Republik Indonesia dan masyarakat sangat berharap banyak dan menumpukan harapan besar kepada lembaga Komisi Pemberantasan Korupsi tersebut didalam upaya mengatasi perbuatan oknum-oknum penyelenggara negara yang bermain dan melakukan perbuatan melawan hukum terhadap uang negara yang dipercaya kewenangan pengelolaannya kepada mereka. Fungsi pengawasan aset dan keuangan negara / anggaran biaya negara yang dipegang oleh salah satu Lembaga atau Badan Negara seperti KPK, telah banyak berhasil mengungkap perbuatan penyalahgunaan keuangan negara dan wewenang oleh penyelenggara negara seperti yang memegang jabatan eksekutif, legislatif dan yudikatif. Oknum-oknum tersebut banyak yang telah menerima ganjaran hukum penjara atas perbuatannya korupsi uang negara atas upaya tugas yang diungkap oleh KPK.

Walaupun harus jujur kita akui bahwa perilaku Korupsi, Kolusi, Nepotisme $(\mathrm{KKN})$ sudah umum dan banyak dilakukan oleh para pejabat negara RI di segala tingkatan, baik di pusat atau sampai ke daerah-daerah (Provinsi, Kab / Kota). Dan perbuatan korupsi oleh PNS / ASN dan pihak swasta yang ikut terlibat beberapa kasus yang pernah terjadi dan ditangani oleh Komisi Pemberantasan Korupsi (KPK) di era reformasi sejak tahun 19998 telah banyak terungkap dan telah diselesaikan oleh tim KPK-RI. Para pejabat pemerintahan eksekutif (Menteri, Dirjen, Gubernur, Bupati, Walikota, dan seluruh jajarannya kebawah) sudah banyak tertangkap tangan (OTT) dan telah menerima ganjaran hukuman yang setimpal terhadap perbuatan korupsi yang dilakukannya. Dan tidak ketinggalan juga dari pejabat-pejabat yudikatif (Hakim, Kepala Pengadilan, Kepala Kejaksaan, Jaksa, Panitera) di semua level atau tingkatan baik dari pusat maupun daerah. Pihak legislatif juga sudah banyak yang ditangkap dan dibawa ke pengadilan seperti anggota; DPD-RI/DPR-RI/DPRD-Provinsi/DPRD-Kab/Kota, dan mereka sudah diganjar hukuman sesuai perbuatan masing-masing didalam kasus tindak pidana korupsi.

Prestasi cemerlang tim Komisi Pemberantasan Korupsi (KPK) Republik Indonesia beberapa tahun belakangan ini, menjadikan Lembaga KPK semakin dicintai dan dihargai masyarakat dari segala lapisan. Walaupun uang negara / aset negara yang telah diselamatkan oleh para jawara KPK kadang-kadang masih belum seberapa yang terungkap tuntas, paling tidak orang-orang terbaik bangsa Indonesia tersebut sudah 
berbuat banyak untuk bangsa dan negara tercinta ini. Tidak aneh kalau lembaga anti korupsi ini banyak yang tidak suka dan selalu berusaha untuk melemahkan dan mencaricari kesalahan para komisioner dan pegawainya. Terutama yang banyak takut dan kegerahan adalah para pejabat / tokoh publik, anggota DPD-RI, DPR-RI, para Menteri, ketua-ketua Parpol dan semua pejabat pemerintahan (eksekutif) maupun yudikatif dan legislatif, yang memang pada dasarnya merekalah yang berpeluang melakukan tindak pidana korupsi dan penyalahgunaan wewenang.

Dikatakan dan diisukan bahwa KPK sebagai lembaga Super Body yang menjadi momok dan merasa lebih suci dan benar sendiri. Sampailah pada suatu ketika di tahun 2009 Ketua KPK-RI Antasari Azhar, SH ditangkap dan dipenjarakan setelah melalui persidangan yang panjang. Karena dituduh membunuh seorang pengusaha bernama Nasarudin. Yang mana Nasarudin sedang menjalani proses hukum di KPK karena korupsi uang negara. Ditangkapnya Antasari Azhar, SH membuka lembaran baru bagi Lembaga KPK, dimana pucuk pimpinannya tersandung kasus pembunuhan dan pemerasan. Sejak saat itulah terbongkarlah kasus demi kasus yang melibatkan orang dalam KPK-RI, termasuk para komisionernya. Kasus suap yang melibatkan pimpinan KPK-RI yang dikaitkan dengan kasus pemerasan terhadap tersangka Anggoro Wijoyo bagi proyek pengadaan di Departemen Kehutanan.

Banyak pihak secara personal (oknum) dari berbaga Instansi/Lembaga Negara yang terlibat dalam kasus ini, Para Petinggi Kejaksaan, Kepolisian, Menteri/Kementrian Kehutanan dan juga dari KPK-RI. Antasari Azhar buka mulut, bahwa ada aliran dana (korupsi/suap) yang diterima Komisioner KPK dan pihak-pihak lain terkait dengan kasus korupsi ini. Kasus korupsi yang lebih tepatnya suap yang dilakukan oleh seorang adik pengusaha Anggoro Wijoyo yaitu Anggodo Wijoyo kepada dua orang pimpinan KPK-RI Bibit samad rianto dan Chandra M. Hamzah pada periode 2009, telah membuat heboh negeri ini. Penyidik Kepolisian dan pihak Kejaksaan Agung Republik Indonesia berhadapan dengan KPK-RI. Lembaga/Instansi Hukum yang seharusnya menjadia pelopor pemberantasan korupsi/suap malahan terlibat kasus suap.

Pihak KPK yang notabene banyak menangani dan menyelidiki kasus korupsi di semua Instansi/Lembaga Pemerintah, banyak mengetahui sepak terjang para pejabat publik dan pemegang kewenangan merasa aman dan memegang Kartu Trust (rahasia) 
akhirnya semua Lembaga Hukum tersebut saling bongkar rahasia keterlibatan PetinggiPetinggi Kejaksaan, Kepolisian, Kementrian dalam beberapa kasus korupsi/suap bagi oknum-oknumnya, untuk melindungi dirinya dari segala tuntutan hukum. Maka mulailah genderang perang dibunyikan, oknum Kepolisian, oknum Kejaksaan di level atas (pemegang kewenangan) menyatakan secara implisit perang tanding kekuatan pembuktian. Pihak KPK yang dulunya imagenya bersih dan terpercaya oleh masyarakat, mendapat dukungan besar dari elemen-elemen masyarakat. Bahkan ada pomeo dari seorang petinggi Kepolisian RI bahwa ini perseteruan antara Cicak dan Buaya, Cicak adalah KPK-RI, Buaya adalah Polri.

Membutuhkan waktu yang panjang dan cukup melelahkan dalam penyelesaian kasus Cicak dan Buaya ini. Masing-masing pihak mencari dan membuktikan bahwa seterunyalah yang salah dan terbukti melanggar hukum pidana. Kasus Bibit-Chandra alurnya diambil alih oleh Instansi Kejaksaan. Di Kejaksaan kasus Bibit-Chandra memerlukan perhatian khusus seluruh jajaran Kejaksaan Agung. Apalagi terbongkar juga bahwa Wakil Jaksa Agung dan salah seorang Jaksa Agung Mudanya ikut terlibat dan dilibatkan oleh tersangka suap Anggoro Wijoyo melalui rekaman pembicaraan via seluler. Begitu juga pihak Kepolisian, Kabareskrim Komjen Susno Duaji terindikasi terlibat bertemu dengan tersangka suap/korupsi yang buron ke Singapura Anggoro Wijoyo, dan beliau juga sempat diproses selaku tersangka dan menerima hukuman penjara setelah dinonaktifkan sebagai Kabareskrim Polri.

\section{Deponering Sebagai Produk Hukum Pidana}

Menyimak perjalanan kasus tesebut di atas, penulis melihat bahwa sebenarnya Lembaga/Instansi Pemerintah seperti Kejaksaan, Polri, KPK dan Pengadilan tidak dapat disalahkan. Yang dapat disalahkan adalah para oknum yang berada di Lembaga/Instansi tersebut yang berperilaku tidak benar dan menjadikan jabatan yang diamanahkan kepadanya tersebut kesempatan untuk melakukan korupsi dalam semua jenis termasuk penyalahgunaan wewenang yang dimilikinya untuk kepentingan pribadinya.

Upaya pelemahan KPK-RI oleh oknum-oknum penyelenggara pemerintahan dan pejabat di beberapa Instansi/Lembaga yang ada di Indonesia, adalah upaya mereka agar tidak ditangkap oleh petugas KPK. Mereka menganggap kebal hukum, karena mereka adalah penegak hukum yang suka mempermainkan hukum, terutama kepada masyarakat 
yang lemah/tak berdaya. Peran Presiden Republik Indonesia seharusnya lebih tajam lagi terhadap menyikapi perseteruan Lembaga/Instansi yang dibawahnya (KPK, Polri, Kejaksaan) tidak hanya menonton dan menunggu hasl saja. Pada kasus Bibit-Chandra, Presiden Susilo Bambang Yudhoyono sempat turun tangan membentuk Tim-8 yang diketuai oleh Advokat senior Adnan Buyung Nasution, yang bertugas selama 14 hari mencari dan menyelidiki fakta yang terjadi sebenarnya terhadap kasus korupsi/suap yang melibatkan dua orang pimpinan KPK Bibit-Chandra.

Presiden RI pemegang kekuasaan tertinggi atas pemerintahan (eksekutif), memang secara hukum tidak boleh ikut campur untuk urusan yudikatif (peradilan/hukum). Itulah yang selalu menjadi kendala Presiden untuk ikut turun tangan terhadap persoalan hukum yang melibatkan Instansi/Lembaga dibawah perintahnya. Sistem hukumm di Indonesia menurut penulis masih banyak yang harus disempurnakan di masa yang akan datang. Hukum ada kalanya tajam ke bawah atau kepada masyarakat bawah/biasa yang tidak berdaya. Sedangkan hukum masih tumpul ke atas atau golongan orang yang memangku jabatan tinggi dan atau punya kekuasaan serta puya uang. Inilah yang menyebabkan terjadinya ketidak adilan bagi setiap warga negara didalam mencari keadilan.

Sikap tegas Presiden juga diharapkan dalam mengatasi setiap permasalahan hukum yang terjadi dalam masyarakat. Karena tanpa adanya ketegasan tersebut, para penegak hukum di lapangan akan bertindak sewenang-wenangnya tanpa memerhatikan asas kesetaraan dalam hukum di RI. Penyelesaian perkara korupsi/suap atas 2 orang pimpinan KPK non aktif (mantan Komisioner KPK) yang memakan waktu cukup lama dan sempat banyak jadi tersangka termasuk Bibit-Chandra dan bahkan juga mengakibatkan petinggi Polri Komjen Pol Susno Duaji dipenjara, menjadi sejarah kelam bagi sistem hukum pidana di Indonesia. Karena begitu banyaknya para oknum penegak hukum dari berbagai Instansi/Lembaga yang terlibat dan atau dilibatkan, garagara kasus korupsi yang dilakukan oleh adiknya Anggodo Wijoyo dan kawan-kawan yang telah mengobrak-abrik dan memporak porandakan keimanan dan prinsip-prinsip hukum dengan iming-iming dan pemberian suap uang kepada oknum-oknum petinggi penegak hukum yang terlibat. 
Putusan dikeluarkannya Deponering terhadap perkara korupsi/suap BibitChandra oleh Jaksa Agung dengan pertimbangan kepentingan umum dan desakan masyarakat banyak yang mendukung Bibit-Chandra karena keyakinan adanya kriminalisasi KPK oleh berbagai pihak baik secara perorangan maupun kelembagaan ada benarnya ada pula salahnya, benar karena memang pertimbangan kepentingan umum dan stabilitas keamanan negara saat itu agar situasi dalam masyarakat kondusif dan aman. Salahnya menurut penulis bahwa kesetaraan di dalam hukum berarti bagi setiap warga negara yang melanggar hukum pidana atau perdata dll, wajib dihukum sesuai/setimpal sesuai peraturan hukum yang ada, tanpa membedakan kedudukannya di masyarakat. Penegakan hukum haruslah adil tanpa terkecuali dan mendahulukan supremasi hukum bagi setiap warga negara.

Deponering memang hak Jaksa Agung sesuai UU tentang Kejaksaan, namun penulis juga berpendapat bahwa putusan Deponering jangan pilih kasih dan dipilihpilih. Harus memperhatikan dan merujuk pada rasa keadilan kepada setiap warga negara, jangan hanya karena oknum tersangka yang memegang kartu/rahasia kebusukan Lembaga/Instansi/oknum pejabat penegak hukum atau pejabat pemerintah, putusan Deponering dikeluarkan dengan alasan atau pertimbangan kepentigan umum dan kenyamanan masyarakat. Masyarakat sudah banyak yang tau tentang sepak terjang penyelenggara pemerintahan dari masa ke masa dengan segala tindak tanduknya. Reformasi 1998 yang diharapkan dapat memperbaiki situasi negara yang penuh dengan gejolak di bidang ekonomi, idiologi, politik dan keamanan, ternyata belum dapat dibuktikan cita-cita luhur menjatuhkan pemerintahan orde baru tersebut, dan bahkan ada indikasi semakin parah saja negeri ini.

Dibutuhkan orang-orang yang mumpuni untuk mengurus negeri ini, tadinya jatuhnya Pak Harto, kita akan memiliki pemimpin negera yang jujur, berkomitmen dan lebih pintar serta cinta NKRI yang mengharamkan korupsi. Tapi ternyata sudah berapa kali ganti Presiden dan Pemerintahan, rakyat masih banyak yang sengsara dan penegakan supremasi hukum masih dalam khayalan dan entah kapan itu akan terjadi, hanya Tuhanlah yang Maha Tahu tentang apa yang akan terjadi terhadap negara dan bangsa Indonesia ini kedepannya. 


\section{Alasan Jaksa Agung Memutus Deponering Terhadap Kasus Bibit - Chandra}

Jaksa Agung memiliki wewenang untuk mendeponering suatu kasus. Kewenangan itu diatur dalam KUHP dan Pasal 23 huruf c UU 16 Tahun 2004 tentang Kejaksaan. Dalam penjelasan Pasal 35 huruf c itu disebutkan bahwa deponering sebagai pelaksanaan asas oportunitas yang dimiliki Jaksa Agung dilakukan setelah mendapatkan saran dan pendapat dari badan kekuasaan negara yang mempunyai hubungan dengan masalah tersebut.

Pada hari Jumat tanggal 29 Oktober 2010 pihak Kejaksaan Agung mengumumkan Deponering atau mengesampingkan perkara terhadap kasus pimpinan KPK Bibit dan Chandra, yang dikukuhkan dengan ketetapan Jaksa Agung nomor 001/A/JA/01/2011 untuk Chandra 002/A/JA/01/2011 pada tanggal 24 Januari 2011 yang mana keduanya disangka telah melakukan tindakan pidana korupsi.

Pengenyampingan perkara demi kepentingan umum tersebut didasarkan pada pertimbangan bahwa apabila perkara atas nama tersangka Chandra M. Hamzah dan Bibit samad rianto dilimpahkan ke pengadilan akan dapat berakibat terganggunya kinerja Komisi Pemberantasan Korupsi (KPK) dalam melakukan tugas dan kewewenangannya, sehingga merugikan kepentingan umum yaitu kepentingan bangsa, negara atau masyarakat. "Pemberantasan korupsi adalah suatu agenda yang harus dilaksanakan, sehingga upaya menyelamatkan harus dilakukan dan itu unsur kepentingan umum" kata Plt. Jaksa Agung Darmono. Selain itu usulan deponering diusulkan tim yang mengurusi masalah ini. Darmono menyatakan apa yang diputuskan Jaksa Agung bukan semata-mata untuk melindungi KPK, tapi dalam rangka melindungi kepentingan yang lebih luas "Dalam rangka melindungi upaya pemberantasan korupsi secara menyeluruh".

Darmono menambahkan pemberantasan korupsi bukan tugas KPK saja, tetapi Kejaksaan Agung juga "Karena ada atau tidak ada KPK, Kejaksaan akan tetap melaksanakan fungsi penegakan hukum dalam rangka pemberantasan korupsi sesuai yang diamanahkan Undang-Undang, sehingga pemberantasan KPK adalah dalam rangka memperkuat upaya pemberantasan korupsi di Indonesia." Darmono mengatakan jika kasus Bibit - Chandra dipaksakan dilanjutkan ke pengadilan, akan berdampak pada kinerja KPK baik secara teknik maupun manajerial. 


\section{PENUTUP}

1. Kedudukan lembaga deponering sebagai implementasi asas oportunitas oleh Jaksa Agung adalah suatu penuntutan haruslah dapat dilakukan jika telah terpenuhi syaratsyarat formil dan haruslah pula dianggap perlu untuk kepentingan umum, sehingga jaksa tidak akan menuntut suatu perkara sebelum unsur kepentingan umum tersebut telah terpenuhi, yaitu apakah suatu penuntutan itu benar-benar dikehendaki oleh kepentingan umum atau tidak. Pengaturan mengenai asas oportunitas sesuai dengan perundang-undangan terkait Undang-Undang Kejaksaan Republik Indonesia yang mengatur sebagai salah satu proses deponering antara lain:

a. Pasal 8 Undang-Undang Nomor 15 Tahun 1961 tentang ketentuan-ketentuan pokok Kejaksaan Republik Indonesia

b. Pasal 32 huruf c Undang-Undang Nomor 5 Tahun 1991 tentang Kejaksaan Republik Indonesia

c. Pasal 35 huruf c Undang-Undang Nomor 16 Tahun 2004 tentang Kejaksaan Republik Indonesia

2. Alasan Jaksa Agung memutuskan deponering terhadap kasus Bibit Samad Rianto dan Chandra M. Hamzah adalah karena didasarkan pada pertimbangan bahwa apabila perkara atas nama tersangka Bibit Samad Rianto dan Chandra M. Hamzah dilimpahkan ke pengadilan akan dapat berakibat terganggunya kinerja Komisi Pemberantasan Korupsi (KPK) baik secara teknik maupun manajerial dalam melakukan tugas dan kewewenangannya, sehingga merugikan kepentingan umum yaitu kepentingan bangsa, negara atau masyarakat dan juga dalam rangka melindungi upaya pemberantasan korupsi secara menyeluruh.

\section{DAFTAR PUSTAKA}

Undang-Undang Dasar Negara Republik Indonesia Tahun 1945.

Undang-Undang Nomor 1 Tahun 1946 Tentang Peraturan Hukum Pidana (KUHP)

Undang-Undang Nomor 8 Tahun 1981 Tentang Hukum Acara Pidana. (KUHAP)

Undang-Undang Nomor 16 Tahun 2004 Tentang Kejaksaan Republik Indonesia.

Peraturan Pemerintah Nomor 58 Tahun 2010 Tentang Perubahan Atas Peraturan Pemerintah Nomor 27 Tahun 1983 Tentang Pelaksanaan Kitab Undang-Undang Hukum Acara Pidana. 